\title{
Effect of Mulching Material on Growth, Yield and Quality of Watermelon (Citrullus Lanatus Thunb) Cv. Kiran
}

\author{
Parmar H. N., N. D. Polara , R. R. Viradiya \\ Department of Horticulture, College of Agriculture, Junagadh Agricultural University, Junagadh-362 001 (Gujarat) \\ *Corresponding Author: ndpolara@jau.in
}

Copyright (c) 2013 Horizon Research Publishing All rights reserved.

\begin{abstract}
The field experiment conducted on watermelon (Citrullus lanatus Thunb) cv. Kiran at Fruit Research Station, "Lalbaugh", Department of Horticulture, College of Agriculture, J.A.U., Junagadh during summer season of 2010 to study the effect of different mulching material on growth, yield and quality of water melon cv. Kiran. All the plant growth, yield and quality characters were superior with silver on black polyethylene mulch while, plants without mulch (control) resulted poor growth and yield. With economic point of view, silver on black mulch resulted in the highest net return and found to be more economical with highest cost:benefit ratio.
\end{abstract}

Keywords Mulching, Plastic Mulch, Watermelon

\section{Introduction}

Watermelon (Citrullus lanatus Thunb.) is one of the important cucurbits vegetable crops grown extensively in India and in tropical and sub tropical countries of the world. It is a major river-bed crop of Uttar Pradesh, Rajasthan, Gujarat, Maharashtra and Andhra Pradesh. It is a popular dessert vegetable with year round availability. Cucurbits share about 5.6 per cent of the total vegetables production of India. Mulching in general is a beneficial practice for crop production. Mulch conserves soil moisture, retained heat as well as it suppresses weed growth (Ahmad et al., 2007, Sharfuddin and Ssiddique, 1985).The greatest benefit from plastic mulch is that the soil temperature in the planting bed is raised, promoting faster crop development and earlier harvest. Black plastic mulch can give a harvest earlier by some 7-14 days, while clear plastic may advance the harvest date by 21 days. Soil water loss is reduced under plastic mulch. As a result, a more uniform soil moisture is maintained and irrigation frequency can be reduced. The growth of plants on mulch can be twice that of plants in unmulched soil. Because larger plants will require more water, mulching is not a substitute for irrigation. Black and white on black mulches will reduce light penetration to the soil. Weeds cannot generally survive under such mulch. Excess water runs off the impervious mulch. Fertilizer beneath the mulch is not lost by leaching, so that fertilizers are optimally used and not wasted. The soil under plastic mulch remains loose, friable and well-aerated. Roots have access to adequate oxygen, and microbial activity is enhanced. Cultivation is eliminated, except in the area between the mulched strips. Use of reflective mulches to delay onset of aphid vectored viruses in summer squash has been well documented in the research literature. (Black 1980, Lancaster et al. 1987, Conway et al. 1989 and Lamont et al. 1990). Therefore, considering the importance of different mulching in various vegetable crops, the present investigation was carried out to study the effect of different mulching material on growth, yield and quality of watermelon.

\section{Materials and Methods}

The field experiment was conducted on water melon cv. Kiran at Fruit Research Station, "Lalbaugh”, Department of Horticulture, College of Agriculture, Junagadh Agricultural University, Junagadh during summer 2010. The experiment was laid out in Randomized Block Design with three replications. There were total eight treatment of mulching materials viz., control $\left(\mathrm{T}_{1}\right)$, wheat straw $\left(\mathrm{T}_{2}\right)$, silver on black polyethylene mulch $\left(\mathrm{T}_{3}\right)$, yellow on black polyethylene mulch $\left(\mathrm{T}_{4}\right)$, red on black polyethylene mulch $\left(\mathrm{T}_{5}\right)$, black on white polyethylene mulch $\left(\mathrm{T}_{6}\right)$, white on black polyethylene mulch $\left(\mathrm{T}_{7}\right)$ and dry leaves mulch $\left(\mathrm{T}_{8}\right)$. Mulching applied up to $50 \mathrm{~cm}$ both the side from the stem of watermelon. Temperature and moisture content will be carried out at 10 $\mathrm{cm}$ and $15 \mathrm{~cm}$ depth. The thickness of all polyethylene much was 30 micron while dry leaves and wheat straw much was applied at 6 inch thick. Single seed of cv. Kiran" was dibbled at each hill on $23^{\text {rd }}$ March 2010 at $2 \mathrm{~m} \mathrm{x} 1 \mathrm{~m}$ spacing. The fertilizers were applied at the rate of 100:50:50 NPK kg/ha. Full dose of $\mathrm{P}_{2} \mathrm{O}_{5}$ and $\mathrm{K}_{2} \mathrm{O}$ was applied as basal dose and nitrogen was given in two equal split as basal and top dressing at 30 DAS. The farmyard manure @ 20 tonnes per hectare was mixed in soil uniformly to all the treatments. The observations on growth, flowering, yield and quality parameters were recorded and subjected to statistical analysis of variance technique as described by Panse and Sukhatme (1985). 
Table 1. Effect of different mulching material on growth and yield of watermelon cv. Kiran

\begin{tabular}{|c|c|c|c|c|c|c|c|c|c|c|c|c|c|}
\hline \multirow{2}{*}{$\begin{array}{l}\text { Sr. } \\
\text { No. }\end{array}$} & \multirow[t]{2}{*}{ Treatments } & \multirow{2}{*}{$\begin{array}{c}\text { No. of } \\
\text { branches per } \\
\text { vine }\end{array}$} & \multicolumn{4}{|c|}{ Vine length $(\mathrm{cm})$} & \multirow{2}{*}{$\begin{array}{l}\text { No. of } \\
\text { node }\end{array}$} & \multirow{2}{*}{$\begin{array}{l}\mathrm{M}: \mathrm{F} \\
(\mathrm{sex}) \\
\text { ratio }\end{array}$} & \multirow{2}{*}{$\begin{array}{c}\text { Fruit } \\
\text { length } \\
(\mathrm{cm})\end{array}$} & \multirow{2}{*}{$\begin{array}{l}\text { Fruit } \\
\text { girth } \\
(\mathrm{cm})\end{array}$} & \multirow{2}{*}{$\begin{array}{c}\text { No. of } \\
\text { fruits/ } \\
\text { vine }\end{array}$} & \multirow{2}{*}{$\begin{array}{c}\text { Fruit } \\
\text { wt. } \\
(\mathrm{kg})\end{array}$} & \multirow{2}{*}{$\begin{array}{c}\text { Fruit yield } \\
\left(\mathrm{t} \mathrm{ha}^{-1}\right)\end{array}$} \\
\hline & & & $30 \mathrm{DAS}$ & $45 \mathrm{DAS}$ & 60 DAS & Harvest & & & & & & & \\
\hline $\mathrm{T}_{1}$ & Control (no mulch) & 7.40 & 83.85 & 105.56 & 117.49 & 159.67 & 42.78 & 5.97 & 28.03 & 14.59 & 2.17 & 2.80 & 22.59 \\
\hline $\mathrm{T}_{2}$ & Wheat straw & 11.07 & 94.12 & 112.68 & 138.52 & 185.26 & 44.33 & 5.43 & 30.01 & 15.32 & 2.24 & 2.83 & 25.37 \\
\hline $\mathrm{T}_{3}$ & Silver on black & 14.90 & 125.13 & 156.37 & 180.27 & 224.97 & 59.58 & 4.57 & 37.45 & 17.62 & 3.23 & 3.61 & 35.37 \\
\hline $\mathrm{T}_{4}$ & Yellow on black & 11.00 & 104.13 & 123.03 & 139.31 & 178.23 & 49.07 & 5.31 & 32.90 & 16.19 & 2.45 & 3.04 & 26.30 \\
\hline $\mathrm{T}_{5}$ & Red on black & 13.43 & 110.74 & 132.61 & 146.06 & 190.00 & 52.34 & 4.63 & 33.13 & 16.57 & 2.73 & 3.35 & 30.37 \\
\hline $\mathrm{T}_{6}$ & Black on white & 13.63 & 116.44 & 142.11 & 161.01 & 206.62 & 57.86 & 4.93 & 35.35 & 17.68 & 2.97 & 3.56 & 33.52 \\
\hline $\mathrm{T}_{7}$ & White on black & 12.83 & 100.61 & 120.48 & 143.53 & 189.67 & 49.16 & 5.20 & 31.12 & 15.08 & 2.46 & 3.05 & 29.26 \\
\hline \multirow[t]{4}{*}{$\mathrm{T}_{8}$} & Dry leaves mulch & 10.67 & 99.26 & 118.14 & 140.08 & 186.67 & 45.62 & 5.07 & 30.14 & 15.07 & 2.30 & 2.97 & 25.56 \\
\hline & S.Em. \pm & 0.599 & 5.100 & 5.280 & 6.376 & 7.866 & 2.369 & 0.297 & 1.390 & 0.770 & 0.121 & 0.132 & 1.229 \\
\hline & C.D. at $5 \%$ & 1.82 & 15.47 & 16.02 & 19.34 & 23.86 & 7.19 & NS & 4.22 & NS & 0.37 & 0.40 & 3.73 \\
\hline & C.V. \% & 8.74 & 8.47 & 7.24 & 7.57 & 7.17 & 8.19 & 10.01 & 7.46 & 8.33 & 8.18 & 7.23 & 7.46 \\
\hline $\begin{array}{l}\text { Sr. } \\
\text { No. }\end{array}$ & Treatments & $\begin{array}{l}\text { Fruit pulp wt. } \\
\text { (g) }\end{array}$ & $\begin{array}{l}\text { Rag wt. } \\
\text { (g) }\end{array}$ & $\begin{array}{c}\text { No. of } \\
\text { seed/fruit }\end{array}$ & $\begin{array}{l}\text { TSS } \\
(\%)\end{array}$ & $\begin{array}{c}\text { Acidity } \\
(\%)\end{array}$ & $\begin{array}{l}\text { Reducing } \\
\text { sugar (\%) }\end{array}$ & \multicolumn{2}{|c|}{$\begin{array}{l}\text { Non reducing } \\
\text { sugar }(\%)\end{array}$} & \multicolumn{2}{|c|}{ Total sugar (\%) } & $\begin{array}{l}\text { Av. soil } \\
\text { temp. }\end{array}$ & $\begin{array}{c}\text { Moisture } \\
(\%)\end{array}$ \\
\hline $\mathrm{T}_{1}$ & Control (no mulch) & 1983.33 & 860.00 & 516.00 & 10.07 & 0.44 & 1.27 & \multicolumn{2}{|c|}{2.90} & \multicolumn{2}{|c|}{4.17} & 33.7 & 47.5 \\
\hline $\mathrm{T}_{2}$ & Wheat straw & 2101.33 & 843.33 & 524.67 & 10.20 & 0.41 & 1.53 & \multicolumn{2}{|c|}{3.20} & \multicolumn{2}{|c|}{4.73} & 31.6 & 46.3 \\
\hline $\mathrm{T}_{3}$ & Silver on black & 2418.67 & 815.33 & 578.33 & 10.43 & 0.37 & 1.80 & \multicolumn{2}{|c|}{3.67} & \multicolumn{2}{|c|}{5.47} & 30.9 & 48.1 \\
\hline $\mathrm{T}_{4}$ & Yellow on black & 2115.00 & 818.00 & 523.67 & 10.27 & 0.40 & 1.60 & \multicolumn{2}{|c|}{3.50} & \multicolumn{2}{|c|}{5.10} & 32.2 & 45.0 \\
\hline $\mathrm{T}_{5}$ & Red on black & 2185.00 & 853.33 & 546.67 & 10.18 & 0.41 & 1.63 & \multicolumn{2}{|c|}{3.56} & \multicolumn{2}{|c|}{5.19} & 31.6 & 46.0 \\
\hline $\mathrm{T}_{6}$ & Black on white & 2308.67 & 816.33 & 564.33 & 10.24 & 0.36 & 1.76 & \multicolumn{2}{|c|}{3.61} & \multicolumn{2}{|c|}{5.37} & 31.7 & 46.8 \\
\hline $\mathrm{T}_{7}$ & White on black & 2148.67 & 844.67 & 536.33 & 10.24 & 0.38 & 1.59 & \multicolumn{2}{|c|}{3.19} & \multicolumn{2}{|c|}{4.78} & 32.2 & 47.2 \\
\hline $\mathrm{T}_{8}$ & Dry leaves mulch & 2065.33 & 834.00 & 517.67 & 10.24 & 0.40 & 1.57 & \multicolumn{2}{|c|}{3.31} & 4.88 & & 32.1 & 44.7 \\
\hline & S.Em. \pm & 75.339 & 53.337 & 23.666 & 0.378 & 0.017 & 0.099 & & 158 & 0.257 & & - & - \\
\hline & C.D. at $5 \%$ & 228.54 & NS & NS & NS & 0.05 & 0.30 & & .48 & 0.78 & & - & - \\
\hline & C.V. \% & 6.03 & 11.06 & 7.61 & 6.40 & 7.22 & 10.77 & & .16 & 8.93 & & - & - \\
\hline
\end{tabular}

$\mathrm{NS}=$ non significant 


\section{Results and Discussion}

\subsection{Effect on Growth and Yield}

The results revealed that different types of mulching materials significantly influenced the growth parameters of watermelon viz., number of branches per vine, main vine length and number of nods per vine over control. Among different mulching treatments, treatment T3 (Silver on black plastic mulch) resulted higher number of branches per vine, increased main vine length and number of nods per vine. However control recorded the minimum growth. The increase in growth parameters was attributed to sufficient soil moisture near root zone and minimized the evaporation loss due to mulching. The extended retention of moisture and availability of moisture also leading to higher uptake of nutrient for proper growth and development of plants, resulted higher growth of plant, as compared to control. The changes in soil temperature below PE mulch could be attributed to different manners of heating and heat transfer to soil and also to heat accumulation during day and loss during night. Similar findings have also been obtained by Dean ban et al. (2004), Ansary and Roy (2005) in wateremelon, Al-Majali and Kasrawi (1995) in muskmelon, Hallidri (2001) in cucumber, Alemayehu-Ambaye and Joseph (2002) in melon, Sharma and Agrawal Narendra (2004) in tomato, Angrej-Ali and Gaur (2007) in strawberry, Aruna et al. (2007) in tomato.

The results indicated that the effect of different mulching material on fruit length of watermelon was significantly increased than control. Maximum fruit length was observed in treatment silver on black plastic mulch, whereas the minimum fruit length of watermelon was noted in control. The highest fruit length under silver on black mulch was due to congenial soil moisture results higher uptake of nutrition for better growth of fruit, the reduction in evaporation losses of soil moisture caused by mulches covered the soil surface in row of watermelon. The above results were in consonance with those of Johnson et al. (2000), Ansary and Roy (2005) in watermelon, Sharma and Agrawal Narendra (2004) in tomato, Suresh and Ashok kumar (2006) in pointed gourd.

Silver on black polyethylene mulch was found to have significantly better effect on the extent of fruit set than other mulching materials tried. This mulch consistently increased higher fruit set than other mulch and no mulch. This might have been influenced by favourable soil temperature, moisture conditions and pest-disease control as influenced by silver on black mulch. The present finding was in accordance with Andino and Motsenbocker (1998), Johnson et al. (2000), Ansary and Roy (2005) in watermelon and Hanna (2000) in cucumber.

It was found that all treatments of mulching material were significantly increased the average fruit weight $(\mathrm{kg})$ of watermelon than control. Among all mulching treatments, maximum average fruit weight was recorded in treatment silver on black mulch. It appears that silver on black polyethylene mulch might have induced favourable conditions conducive to attainment of fruits with higher weight. The above results were in agreement with those of
Ansary and Roy (2005), Arancibia and Motsenbocker (2008) in watermelon, Sharma and Agrawal Narendra (2004), Aruna et al. (2007) in tomato and Angrej-Ali and Gaur (2007) in strawberry.

It was found that all the treatments of mulching material were significantly increased the fruit yield of watermelon. Among all mulching treatments, maximum fruit yield recorded in treatment silver on black polyethylene mulch. Yield of watermelon was higher in plants mulched with silver on black polyethylene, which was higher as compare to other mulch and no mulch. Plants under polyethylene mulch (silver on black) produced larger fruit and have higher fruit yield per vine because of better plant growth due to favourable hydro-thermal regime of soil and complete weed free environment. The above results were in consonance with those of Rudich et al.(1978), Battikhi and Ghawi (1987), Bhella (1988), Qadir (1992), Al-Majali and Kasrawi (1995), Johnson et al. (2000), Dean ban et al. (2004), Ansary and Roy (2005), Cenobio et al. (2007) and Arancibia and Motsenbocker (2008) in watermelon, Siwek and Kunicki (1998), Ibarra-Jimenez et al. (2008), Hallidri (2001) in cucumber, Ibarra et al. (2001) in muskmelon.

\subsection{Effect on Quality}

The data indicated that the effect of various treatments of mulching material on quality parameters viz., Total soluble solid, fruit pulp weight (g), acidity (\%), reducing sugar, total sugar and non-reducing sugar was found significant in fruit of watermelon. It was found that all treatments of mulching material were significantly increased the fruit pulp weight of watermelon but it was unable to exert a significant influence on rag weight and number of seeds per fruit than control. Among all treatments of mulching, maximum fruit pulp weight was recorded in treatment silver on black mulch. An increase in fruit pulp weight in mulched plants may further attributed to the reason that plants remain physiologically more active to build up sufficient food stock for the developing fruits. The above results were in agreement with those of Suresh and Ashok Kumar (2006) in pointed gourd, Angrej-Ali and Gaur (2007) in strawberry, Aruna et al. (2007) in tomato, Aruna and Roy (2005) in watermelon.

It was found that application of mulching material had produced a significant effect on acidity per cent in fruit of watermelon than control. Among all the treatments of mulching significantly minimum acidity were observed in treatment silver on black mulch over control. The present finding was in accordance with Sharma and Agrawal Narendra (2004) and Aruna (2007) in tomato. The total soluble solids $(\%)$, reducing sugars $(\%)$, total sugar $(\%)$ and non reducing sugar (\%) were significantly increased than the control. Among all treatments of mulching, maximum TSS, reducing sugars, total sugar and non-reducing sugar of watermelon fruit were observed in treatment silver on black mulch. While, the minimum sugar content of watermelon fruit was observed in control treatment. The present findings were in close confirmation with Ansary and Roy (2005) in watermelon, Sharma and Agrawal Narendra (2004) and Aruna et al. (2007) in tomato. 
Table 3. Effect of different mulching material on economics of watermelon cv. Kiran

\begin{tabular}{|c|c|c|c|c|c|c|}
\hline Sr.No. & Treatments & $\begin{array}{l}\text { Yield } \\
\left(\mathrm{t} \mathrm{ha}^{-1}\right)\end{array}$ & $\begin{array}{c}\text { Gross realization } \\
\left(\text { Rs. } \text { ha }^{-1}\right)\end{array}$ & $\begin{array}{c}\text { Total Expenditure } \\
\left(\text { Rs. } \text { ha }^{-1}\right)\end{array}$ & $\begin{array}{l}\text { Net realization } \\
\left(\text { Rs. } \text { ha }^{-1}\right)\end{array}$ & $\mathrm{CBR}$ \\
\hline $\mathrm{T} 1$ & Control (no mulch) & 22.59 & 225900 & 209770 & 16130 & 1:1.08 \\
\hline $\mathrm{T} 2$ & Wheat straw & 25.37 & 253700 & 210120 & 43580 & $1: 1.21$ \\
\hline $\mathrm{T} 3$ & Silver on black & 35.37 & 353700 & 214480 & 139220 & $1: 1.65$ \\
\hline $\mathrm{T} 4$ & Yellow on black & 26.30 & 263000 & 214480 & 48520 & $1: 1.23$ \\
\hline T5 & Red on black & 30.37 & 303700 & 214480 & 89220 & $1: 1.42$ \\
\hline T6 & Black on white & 33.52 & 335200 & 214480 & 120720 & $1: 1.56$ \\
\hline $\mathrm{T} 7$ & White on black & 29.26 & 292600 & 214480 & 78120 & $1: 1.36$ \\
\hline $\mathrm{T} 8$ & Dry leaves mulch & 25.56 & 255620 & 209790 & 45830 & $1: 1.22$ \\
\hline
\end{tabular}

Price: Watermelon@ Rs.10 kg ${ }^{-1}$, mulching material @ Rs. $3.5 \mathrm{~m}^{-2}$

It was observed from Table 3 that highest net return with maximum CBR was obtained with treatment silver on black mulch followed by treatments black on white mulch. The lowest net return with minimum CBR was obtained in control (no mulch). The net realization was increased due to different mulches as compared to control treatment. The treatment of silver on black mulch recorded higher fruit yield though higher net realization was recorded under this treatment silver on black mulch. These findings are in close agreement with the results of Singh et al. (2006) in cabbage, Suresh and Ashok Kumar (2006) in pointed guard and Balraj Singh et al. (2007) in bittergourd.

\section{Conclusions}

It is concluded that application of mulches over contro is beneficial to farmers. Higher the CBR, needs to be adopted first by farmers based on availability of mulch material and other priority criteria.

\section{REFERENCES}

[1] Alemayehu Ambaye and Joseph, P. A. (2002). Influence of drip irrigation and mulching on soil moisture retention, water use efficiency, growth and yield of oriental pickling melon (Cucumis melo L. var. conoman makino). South Indian Hort., 50(4/6): 421-429.

[2] Al-Majali, M. A. and Kasrawi, M. A. (1995). Plastic mulch use and method of planting influences on rainfed muskmelon production. Pure and Applied Sci., 22(4): 1039-1054.

[3] Andino, J. R. and Motsenbocker, C. E. (1998). Coloured plastic mulches influence cucumber beetle populations, vine growth and yield of watermelon. Hort. Sci., 39(6):1246-1249.

[4] Angrej Ali and Gaur, G. S. (2007). Effect of mulching on growth, fruit yield and quality of strawberry (Fragaria $\mathrm{x}$ ananassa Duch.). Asian J. Hort., 2(1): 149-151.
[5] Ansary, S.H. and Roy, D. C. (2005). Effect of irrigation and mulching on growth, yield and quality of watermelon (Citrullus lanatus Thunb.). Environment and Ecology, 23(Spl-1): 141-143.

[6] Arancibia, R. A. and Motsenbocker, C. E. (2008). Differential watermelon fruit size distribution in response to plastic mulch and spunbonded polyester rowcover. Hort.Tech., 18(1): 45-52.

[7] Aruna, P.; Sudagar, I.P.; Manivannan, M. I.; Rajangam, J and Natarajan, S. (2007). Effect of fertigation and mulching for yield and quality in tomato cv. PKM-1. Asian J. Hort., 2(2): 50-54.

[8] Balraj Singh; Mahesh Kumar and Mehto, S. P. (2007). Advancing bitter gourd crop by plastic mulching: a profitable and sustainable technology for peri-urban areas of Northern India. Acta Hort., 731: 199-201.

[9] Battikhi, A. M. and Ghawi, I. (1987). Muskmelon production under mulch and trickle irrigation in the Jordan valley. Hort. Sci., 22(4): 578-581.

[10] Bhella, H. S. (1988). Effect of trickle irrigation and black mulch on growth, yield and mineral composition of watermelon. Hort. Sci., 23(1):123-125.

[11] Cenobio Pedro, G.; Inzunza Ibarra, M. A.; Mendoza Moreno, S. F.; Sanchez Cohen, I.; and Roman Lopez, A. (2007). Response of watermelon to colored plastic mulches under drip irrigation. Terra., 24(4): 515-520.

[12] Dean Ban.; Zanic K.; Dumicic, G.; Culjak, T. G. and Ban S. G. (2004). The type of polythene mulch impacts vegetative growth, yield and aphid populations in watermelon production. J. Food, Agri. and Envi., 7 (3-4): 543-550.

[13] Hallidri, M. (2001). Comparison of the different mulching materials on the growth, yield and quality of cucumber (Cucumis sativus L.). Acta Hort., 559: 49-54.

[14] Hanna, H. Y. (2000). Black polyethylene mulch does not reduce yield of cucumbers double-cropped with tomatoes under heat stress. Hort. Sci., 35(2): 190-191.

[15] Ibarra Jimenez, L.; Zermeno Gonzalez, A.; Munguia Lopez, J.; Quezada Martin, M. A. R. and Rosa Ibarra, M. de La. (2008). Photosynthesis, soil temperature and yield of 
cucumber as affected by colored plastic mulch. Acta Agriculturae Scandinavica Section B, Plant Soil Science, 58(4): 372-378.

[16] Ibarra, L.; Flores, J. and Diaz Perez J. C. (2001). Growth and response to plastic mulch and row covers. Scientia Horticulturae, 87(1/2): 139-145.

[17] Johnson J. M.; Hough Goldstein J. A. and Vangessel M. J. (2000). Effects of Straw Mulch on Pest Insects, Predators, and Weeds in Watermelons and Potatoes. Environmental Entomology, 33: 1632-1643.

[18] Rudich, J.; Elassar, G. and Shefi, Y. (1978). Optimal growth stages for the application of drip irrigation to muskmelon and watermelon. J. Hort. Sci., 53(1): 11-15.
[19] Sharma, H. G. and Agrawal, Narendra (2004). Effect of different colour mulches on the growth and yield of tomato under drip irrigation. Plant Archives., 4(1): 93-99.

[20] Singh, V. P.; Singh, R. P.; Arora, S. K.; Godara, A. K.; Yadav, B. S. (2006). Effect of black polythene mulch on growth and fruit yield of tomato. Haryana J. Hort. Sci., 35(3/4): 323.

[21] Siwek, P and Kunicki,(1998). Ecological aspects of mulching with polyethylene film in early cucumber cultivation. Roczniki Akademii Rolniczej-w-Poznaniu, Ogrodnictwo., 27: 277-283.

[22] Suresh, R. and Ashok Kumar (2006). Effect of drip irrigation and mulch on pointed gourd in calcareous soil of north Bihar. Indian J. Soil Cons., 34(1): 83-8 